
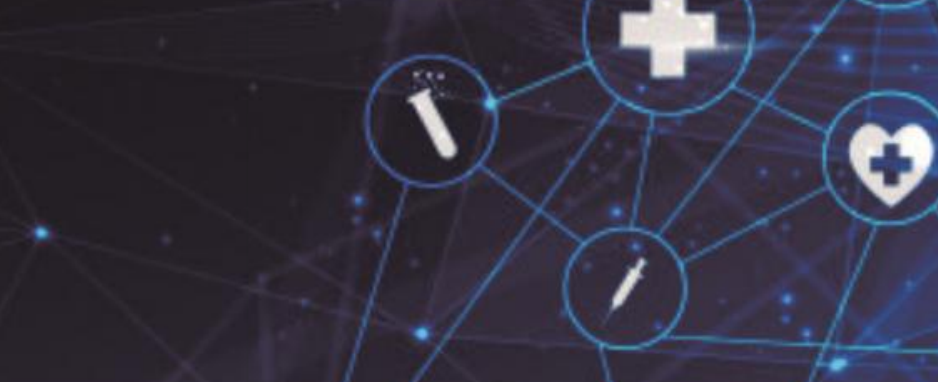

ARTIKEL RISET

http://inajoh.org/index.php/INAJOH/articel

\title{
Karakteristik Pasien ISPA Pada Pasien Balita Di Puskesmas Sudiang Raya
}

\section{Andi Muhammad Fadilah Mursyid ${ }^{1}$}

${ }^{1}$ Departemen Ilmu Kesehatan Masyarakat, Fakultas Kedokteran, Universitas Muslim Indonesia mursyidfadil@gmail.com ${ }^{\mathrm{k}}$ mursyidfadil@gmail.com ${ }^{1}$, 085342986454

\section{ABSTRAK}

Latar belakang : Penyakit Infeksi Saluran Pernapasan Akut (ISPA) merupakan salah satu masalah kesehatan yang ada di negara berkembang dan negara maju. Tujuan Penelitian : Tujuan dari penelitian ini adalah untuk mengetahui karakteristik pasien ISPA pada balita di puskesmas sudiang raya. Metode Penelitian : Penelitian yang dilakukan adalah penelitian deskriptif dengan menggunakan pendekatan observasional untuk melihat gambaran karakteristik pasien ISPA di Puskesmas Sudiang Raya. Karakteristik yang dimaksud berupa jenis kelamin, usia, status gizi dan faktor lingkungan. Hasil Penelitian : Dari 250 orang dapat diketahui bahwa jumlah pasien laki - laki dengan ISPA yaitu berjumlah 124 orang $(49,6 \%)$ dan jumlah pasien perempuan dengan ISPA yaitu berjumlah 126 orang (50,4\%). jumlah pasien anak di atas 5 tahun yaitu berjumlah 68 orang $(27,2 \%)$. Sedangkan jumlah pasien anak usia 3-5 tahun yaitu berjumlah $90(36,0 \%)$ dan pasien usia di bawah 3 tahun berjumlah 92 orang (36,8\%). Jumlah pasien anak yang mengalami gizi baik yaitu berjumlah 52 orang $(20,8 \%)$. Sedangkan jumlah pasien anak yang mengalami gizi kurang yaitu berjumlah 112 orang (44,8\%) dan pasien anak yang mengalami gizi buruk berjumlah 86 orang $(34,4 \%)$. Diketahui bahwa ada perokok dalam keluarga sebanyak 194 orang (77,6\%). Sedangkan yang tidak merokok dalam keluarga sebanyak 56 orang $(22,4 \%)$. Kesimpulan : Dengan mengacu kepada hasil yang didapatkan, maka dapat dikatakan bahwa tidak hanya dengan menggunakan obat dapat mengendalikan kasus-kasus ISPA pada balita, tetapi dengan mengontrol beberapa faktor resiko juga dapat menurunkan kejadian ISPA pada balita.

Kata kunci : ISPA; Karakteristik Pasien ISPA pada balita; Puskesmas Sudiang Raya.

\section{PUBLISHED BY :}

Yayasan Citra Cendekia Celebes

\section{Address :}

Perumahan Bukit Tamalanrea Permai

Blok D No.61 Kota Makassar,

Sulawesi Selatan, Kode Pos : 90211

Email :

inajoh@inajoh.org

Phone :

082346913176

\section{Article history :}

Received 04 Januari 2021

Received in revised form 06 Januari 2021

Accepted 08 Januari 2021

Available online 26 Februari 2021

licensed by Creative Commons Attribution-ShareAlike 4.0 International License. 


\begin{abstract}
Background: Acute Respiratory Infections (ARI) is a health problem that exists in developing and developed countries. Research Objectives: The purpose of this study was to determine the characteristics of ARI patients in children under five at Sudiang Raya Public Health Center. Methods: The study was a descriptive study using an observational approach to describe the characteristics of ARI patients at the Sudiang Raya Community Health Center. The characteristics referred to are gender, age, nutritional status and environmental factors. Results: From 250 people it can be seen that the number of male patients with ISPA is 124 (49.6\%) and the number of female patients with ARI is 126 people (50.4\%). The number of children over 5 years was 68 (27.2\%). Meanwhile, the number of children aged 3-5 years was 90 (36.0\%) and patients under 3 years old were 92 (36.8\%). The number of child patients who experienced good nutrition was 52 (20.8\%). While the number of children with malnutrition was 112 (44.8\%) and 86 children with bad gzi (34.4\%). It is known that there are 194 smokers in the family (77.6\%). . Meanwhile, there are no smokers in the family of 56 people (22.4\%). Conclusion: By referring to the results obtained, it can be said that not only by using drugs can control ARI cases in children under five, but controlling for several risk factors can also reduce the incidence of ARI in toddlers.
\end{abstract}

Keywords: ARI; Characteristics of ARI Patients in infants; Sudiang Raya Health Center

\title{
PENDAHULUAN
}

Penyakit Infeksi Saluran Pernapasan Akut (ISPA) merupakan salah satu masalah kesehatan yang ada di negara berkembang dan negara maju. Hal ini dikarenakan masih tingginya angka kesakitan dan angka kematian karena ISPA khususnya pneumonia, terutama pada bayi dan balita. ${ }^{1}$

Pedoman kerja puskesmas membagi ISPA menjadi 3 kelompok besar, yaitu ISPA berat atau pneumonia berat ditandai oleh adanya tarikan dinding dada bagian bawah ke dalam waktu inspirasi. ISPA sedang atau pneumonia bila frekuensi nafas menjadi cepat dan ISPA ringan atau bukan pneumonia, ditandai dengan batuk pilek tanpa nafas cepat, tanpa tarikan dinding dada bagian bawah ke dalam, seperti misalnya nasofaringitis, faringitis, rinofaringitis, dan lain sebagainya. Khusus untuk bayi dibawah 2 bulan hanya dikenal ISPA berat dan ISPA ringan. ${ }^{2}$

Menurut laporan World Health Organization (WHO) tahun 2005, sekitar 19\% atau berkisar 1,6-2,2 juta anak meninggal dunia setiap tahunnya akibat pneumonia. Menurut survei kematian balita tahun 2005, infeksi saluran pernapasan akut (ISPA) masih merupakan masalah kesehatan masyarakat di Indonesia dan sebagian besar disebabkan karena pneumonia 23,6\%. Angka kesakitan diperkirakan mencapai 250 hingga 299 per 1000 anak balita setiap tahunnya. ${ }^{3}$ Tingginya mortalitas bayi dan balita karena ISPA-Pneumonia menyebabkan penanganan penyakit ISPA-Pneumonia menjadi sangat penting artinya kondisi ini disadari oleh pemerintah sehingga dalam program Pemberantasan Penyakit Infeksi Saluran Pernapasan Akut (P2 ISPA) telah menggariskan untuk menurunkan angka kematian balita akibat pneumonia dari 5/1000 balita pada tahun 2000 menjadi 3/1000 pada tahun 2005 dan menurunkan angka kesakitan pneumonia balita dari $10-20 \%$ menjadi $8-16 \%$ pada tahun $2005 .{ }^{3}$

ISPA adalah penyakit yang menyerang salah satu bagian dan atau lebih dari saluran pernapasan mulai dari hidung hingga alveoli termasuk jaringan adneksanya seperti sinus, rongga telinga tengah dan pleura. ${ }^{5}$ Jadi disimpulkan bahwa ISPA adalah suatu tanda dan gejala akut akibat 
infeksi yang terjadi di setiap bagian saluran pernapasan atau struktur yang berhubungan dengan pernapasan yang berlangsung tidak lebih dari 14 hari.

Etiologi ISPA terdiri lebih dari 300 jenis bakteri, virus dan riketsia. Bakteri penyebab ISPA antara lain adalah dari genus Streptokokus, Stafilokokus, Pneumokokus, Hemofillus, Bordetelia dan Korinebakterium. Virus penyebab ISPA antara lain adalah golongan Miksovirus, Adnovirus, Koronavirus, Picornavirus, Mikoplasma, Herpesvirus dan lain-lain. ${ }^{6}$

Data epidemiologi kasus ISPA/pneumonia di Indonesia berdasarkan hasil Riskesdes tahun 2007, menunjukan prevalensi nasional ISPA 25,5\% (16 provinsi di atas angka nasional yaitu Nad, Sumatra utara, Sumatra barat, Riau, Jambi, Sumatera selatan, Bengkulu, Lampung, Bangka belitung, Kepulauan Riau, DKI Jakarta, Jawa barat, NTT, Gorontalo, Papua barat, Sulawesi tengah. Angka kesakitan (morbiditas) pneumonia bayi 2,2\%, angka kesakitan (morbiditas) pneumonia balita 3\%, kematian bayi karena pneumonia (mortalitas) $23,8 \%$ atau kematian balita karena pneumonia (mortalitas) $15,5 \%{ }^{4,6}$

Prevalensi infeksi saluran pernapasan akut (ISPA) menurut riset kesehatan dasar di Indonesia pada tahun 2013 terdapat $(25,0 \%)$ kasus yang tertinggi pada balita usia 1 sampai dengan 4 tahun, ada lima provinsi tertinggi yang menyumbang infeksi saluran pernapasan akut yaitu Nusa Tenggara Timur (41,7\%), Papua (31,1\%), Aceh (30,0\%), Nusa Tenggara Barat (28,3\%), dan Jawa Timur (28,3\%). Yogyakarta sendiri masuk dalam urutan ke 18 dari seluruh provinsi di Indonesia dengan jumlah kasus (23,3\%) dimana kasus tersebut tertinggi pada usia 1-4 tahun. ${ }^{8}$ Pada tahun 2014 tercatat dari rekap laporan pengendalian infeksi saluran pernapasan akut (ISPA) dinas kesehatan kota Yogyakarta pada umur $<1$ tahun insiden infeksi saluran pernapasan akut berjumlah 4.758 jiwa dan pada umur 1-4 tahun insiden infeksi saluran pernapasan akut berjumlah 12.022 jiwa. $^{10,11}$

Klasifikasi penyakit ISPA dibedakan untuk golongan umur di bawah 2 bulan dan untuk golongan umur 2 bulan sampai dengan 5 tahun $^{4}$. Golongan Umur Kurang 2 Bulan terdiri dari Pneumonia Berat apabila disertai salah satu tanda tarikan kuat di dinding pada bagian bawah atau napas cepat. Batas napas cepat untuk golongan umur kurang 2 bulan yaitu 6 kali per menit atau lebih dan Bukan Pneumonia (batuk pilek biasa) apabila tidak ditemukan tanda tarikan kuat dinding dada bagian bawah atau napas cepat. Tanda bahaya untuk golongan umur kurang 2 bulan, yaitu: Kurang bisa minum (kemampuan minumnya menurun sampai kurang dari $1 \frac{2}{2} \quad$ volume yang biasa diminum), Kejang, Kesadaran menurun, Stridor, Wheezing, Demam / dingin.

Golongan Umur 2 Bulan-5 Tahun terdiri dari, pertama Pneumonia Berat apabila disertai napas sesak yaitu adanya tarikan di dinding dada bagian bawah ke dalam pada waktu anak menarik nafas (pada saat diperiksa anak harus dalam keadaan tenang, tidak menangis atau meronta). kedua Pneumonia Sedang apabila disertai napas cepat. Batas napas cepat ialah:, Untuk usia 2 bulan-12 bulan $=50$ kali per menit atau lebih, Untuk usia 1-4 tahun = 40 kali per menit atau lebih. Dan yang ketiga 
bukan Pneumonia apabila tidak ditemukan tarikan dinding dada bagian bawah dan tidak ada napas cepat. Tanda bahaya untuk golongan umur 2 bulan-5 tahun yaitu :, Tidak bisa minum, Kejang, Kesadaran menurun, Stridor, Gizi buruk

Ujunwa (2014) mengemukakan bahwa infeksi pernapasan akut dipengaruhi oleh faktor risiko sosio-demografis dan sosial budaya, yang dapat dimodifikasi dengan strategi sederhana. ${ }^{12}$ sedangkan faktor resiko timbulnya ISPA menurut Dharmage (2009) ${ }^{7}$ terdiri dari faktor Demografi yang terdiri dari 3 aspek yaitu Jenis kelamin, Usia, Pendidikan; Faktor Biologis yaitu Status gizi; dan terakhir Faktor rumah.

ISPA merupakan proses inflamasi yang terjadi pada setiap bagian saluran pernapasan atas maupun bawah, yang meliputi infiltrat peradangan dan edema mukosa, kongestif vaskuler, bertambahnya sekresi mukus serta perubahan struktur fungsi siliare. ${ }^{4}$

Tanda dan gejala ISPA banyak bervariasi antara lain demam, pusing, malaise (lemas), anoreksia (tidak nafsu makan), vomitus (muntah), photophobia (takut cahaya), gelisah, batuk, keluar sekret, stridor (suara nafas), dyspnea (kesakitan bernafas), retraksi suprasternal (adanya tarikan dada), hipoksia (kurang oksigen), dan dapat berlanjut pada gagal nafas apabila tidak mendapat pertolongan dan mengakibatkan kematian. ${ }^{5}$

Sedangkan tanda gejala ISPA menurut Depkes RI (2002) adalah : ${ }^{6}$ Gejala dari ISPA Ringan ketika seorang anak dinyatakan menderita ISPA ringan jika ditemukan satu atau lebih gejala-gejala sebagai berikut: batuk serak, pilek. panas atau demam, suhu badan lebih dari $37^{\circ} \mathrm{C}$. Tanda gejala dari ISPA Sedang ketika seorang anak dinyatakan menderita ISPA sedang jika dijumpai gejala dari ISPA ringan disertai satu atau lebih gejala-gejala sebagai berikut: Pernapasan lebih dari 50 kali per menit pada anak yang berumur kurang dari satu tahun atau lebih dari 40 kali per menit pada anak yang berumur satu tahun atau lebih. Tanda gejala dari ISPA Berat Seorang anak dinyatakan menderita ISPA berat jika dijumpai gejala-gejala ISPA ringan atau ISPA sedang disertai satu atau lebih gejala-gejala sebagai berikut: Bibir atau kulit membiru. Lubang hidung kembang kempis (dengan cukup lebar) pada waktu bernafas. Anak tidak sadar atau kesadaran menurun. Pernapasan berbunyi seperti orang mengorok dan anak tampak gelisah. Sela iga tertarik ke dalam pada waktu bernafas. Nadi cepat lebih dari 160 kali per menit atau tidak teraba. Tenggorokan berwarna merah.

Diagnosis ISPA biasanya didasarkan pada gejala (kurangnya demam dikombinasikan dengan gejala lokalisasi ke nasofaring). Tidak seperti rinitis alergi, eosinofil tidak ada dalam sekresi hidung. Meskipun dimungkinkan untuk mengisolasi virus untuk diagnosis definitif, itu jarang dibenarkan. ${ }^{20}$

Penemuan dini penderita pneumonia dengan penatalaksanaan kasus yang benar merupakan strategi untuk mencapai dua dari tiga tujuan program (turunnya kematian karena pneumonia dan turunnya penggunaan antibiotik dan obat batuk yang kurang tepat pada pengobatan penyakit ISPA). ${ }^{7}$ 
Pedoman penatalaksanaan kasus ISPA akan memberikan petunjuk standar pengobatan penyakit ISPA yang akan berdampak mengurangi penggunaan antibiotik untuk kasus-kasus batuk pilek biasa, serta mengurangi penggunaan obat batuk yang kurang bermanfaat. Strategi penatalaksanaan kasus mencakup pula petunjuk tentang pemberian makanan dan minuman sebagai bagian dari tindakan penunjang yang penting bagi penderita ISPA . Penatalaksanaan ISPA meliputi langkah atau tindakan sebagai berikut: ${ }^{21}$ Pemeriksaan untuk memperoleh informasi tentang penyakit anak dengan mengajukan beberapa pertanyaan kepada ibunya, melihat dan mendengarkan anak. Kemudian klasifikasi ISPA, lalu pengobatan, Perawatan di rumah.

\section{METODE}

Penelitian yang dilakukan adalah penelitian deskriptif dengan menggunakan pendekatan observasional untuk melihat gambaran karakteristik pasien ISPA di Puskesmas Sudiang Raya. Lokasi penelitian yang dipilih adalah di Puskesmas Sudiang Raya. Penelitian ini akan dilaksanakan pada bulan Januari - Mei 2019. Populasi dalam penelitian ini adalah pasien dengan ISPA di Puskesmas Sudiang Raya yang berjumlah 250 orang. Sampel pada penelitian ini adalah pasien dengan ISPA di Puskesmas Sudiang Raya yang berjumlah 250 orang. Menggunakan teknik total sampling. Seluruh sampel yang masuk dalam kriteria sample dijadikan sebagai sampel untuk penelitian ini. Pengolahan data dilakukan secara elektronik dengan menggunakan perangkat lunak komputer program Microsoft Excel 2007 dan SPSS 22 - For windows. Sedangkan penyajian data menggunakan tabel distribusi frekuensi presentasi disertai dengan penjelasan tabel.

\section{HASIL}

Karakteristik sampel berikut ini menjelaskan mengenai distribusi frekuensi dari setiap variabel terkait mengenai jenis kelamin dan usia pasien ISPA di Puskesmas Sudiang Raya. Adapun hasil analisis data tersebut sebagai berikut:

Table 1. Distribusi frekuensi pasien ISPA berdasarkan jenis kelamin

\begin{tabular}{lll}
\hline Interval Usia & Frekuensi & Persentase \\
\hline Laki-Laki & 126 & $50,4 \%$ \\
Perempuan & 124 & $49,6 \%$ \\
\hline Total & 250 & $100 \%$ \\
\hline Sumber : Rekam Medik Puskesmas Sudiang Raya diolah dengan SPSS 22, 2017
\end{tabular}

Berdasarkan Tabel 5.1 dapat diketahui bahwa jumlah jumlah pasien laki - laki dengan ISPA yaitu berjumlah 124 orang $(49,6 \%)$ dan jumlah pasien perempuan dengan ISPA yaitu berjumlah 126 orang $(50,4 \%)$. 
Table 2. Distribusi frekuensi pasien ISPA berdasarkan usia

\begin{tabular}{lcc}
\hline Jenis Kelamin & Frekuensi & Persentase \\
\hline$>5$ tahun & 68 & $27,2 \%$ \\
$3-5$ tahun & 81 & $32,4 \%$ \\
$<3$ tahun & 101 & $40,4 \%$ \\
\hline Total & 250 & $100 \%$ \\
\hline Sumber : Rekam Medik Puskesmas Sudiang Raya diolah dengan SPSS 22, 2017
\end{tabular}

Berdasarkan Tabel 5.2 dapat diketahui bahwa jumlah pasien anak di atas 5 tahun yaitu berjumlah 68 orang $(27,2 \%)$. Sedangkan jumlah pasien anak usia 3-5 tahun yaitu berjumlah 90 $(36,0 \%)$ dan pasien usia dibawah 3 tahun berjumlah 92 orang $(36,8 \%)$.

Table 3. Distribusi frekuensi pasien ISPA berdasarkan status gizi

\begin{tabular}{lcc}
\hline Status Gizi & Frekuensi & Persentase \\
\hline Gizi baik & 52 & $20,8 \%$ \\
Gizi kurang & 112 & $44,8 \%$ \\
Gizi buruk & 86 & $34,4 \%$ \\
\hline Total & 250 & $100 \%$ \\
\hline Sumber : Rekam Medik Puskesmas Sudiang Raya diolah dengan SPSS 22, 2017
\end{tabular}

Berdasarkan Tabel 5.3 dapat diketahui bahwa jumlah pasien anak yang mengalami gizi baik yaitu berjumlah 52 orang $(20,8 \%)$. Sedangkan jumlah pasien anak yang mengalami gizi kurang yaitu berjumlah 112 orang $(44,8 \%)$ dan pasien anak yang mengalami gzi buruk berjumlah 86 orang $(34,4 \%)$.

Tabel 4. Distribusi frekuensi pasien ISPA berdasarkan Faktor lingkungan

\begin{tabular}{lll}
\hline Faktor Lingkungan & Frekuensi & Persentase \\
\hline Ada perokok & 194 & $77,6 \%$ \\
Tidak ada perokok & 56 & $22,4 \%$ \\
\hline Total & 250 & $100 \%$ \\
\hline
\end{tabular}

Sumber : Rekam Medik Puskesmas Sudiang Raya diolah dengan SPSS 22, 2017 
Berdasarkan Tabel 5.4 dapat diketahui bahwa ada perokok dalam keluarga berjumlah 194 orang $(77,6 \%)$. Sedangkan tidak ada perokok dalam keluarga berjumlah 56 orang $(22,4 \%)$.

\section{PEMABAHASAN}

Berdasarkan tabel 1 diatas dapat dilihat bahwa frekuensi terbanyak pasien balita ISPA berjenis kelamin laki-laki sebanyak 126 orang (50,4\% dari keseluruhan pasien balita ISPA), sedangkan balita perempuan sebanyak 124 orang (49,6\% dari keseluruhan pasien balita ISPA). Hasil penelitian ini sejalan dengan penelitian sebelumnya yang menyebutkan bahwa jenis kelamin tidak berhubungan secara signifikan dengan kejadian ISPA pada balita.

Berdasarkan hasil penelitian tabel 2 menunjukkan bahwa persentase pasien ISPA banyak terjadi di usia 0 sampai 3 tahun dengan persentase terbanyak 40,4\% dibandingkan dengan pasien diusia 3 sampai 5 tahun dengan persentase 32,4\%. Sedangkan pasien yang berusia diatas 5 tahun lebih sedikit dengn persentase 27,2\%. sesuai dengan meningkatnya umur. Dari hasil penelitian sebelumnya juga menyebutkan bahwa usia yang paling sering terkena ISPA adalah usia 0-3 tahun. Hasil penelitian sebelumnya juga mengatakan bahwa Balita penderita Infeksi Saluran pernapasan akut paling banyak terjadi pada kelompok umur 12-35 bulan dimana keadaan balita umur $\measuredangle 4$ bulan belum memiliki sistem imun yang sempurna dan lumen pernapasan masih sempit. 17 Balita umur 2-3 tahun merupakan puncak terjadinya pneumonia akibat infeksi virus. Hasil dari penelitian lainnya dari Williams (2002) yang meneliti tentang estimasi jumlah anak balita di dunia yang meninggal karena infeksi pernapasan akut menunjukkan bahwa di seluruh dunia 1 - 9 juta (95\% CI 1 - 6-2 · 2 juta) anak-anak meninggal karena ISPA pada tahun $2000,70 \%$ di antaranya di Afrika dan Asia Tenggara. ${ }^{24}$

Berdasarkan hasil penelitian tabel 3 menunjukkan bahwa persentase pasien ISPA banyak terjadi pada anak yang mengalami gizi buruk dengan persentase terbanyak yaitu 44,8\% dibandingkan dengan anak yang mengalami gizi kurang dengan persentase 34,4\%. Sedangkan pasien anak yang mengalami gizi baik lebih sedikit dengan persentase 20,8\%. Hasil penelitian Fonseca 1996 di Fortaleza Brazil menunjukkan bahwa status gizi kurang menempati urutan pertama faktor resiko terjadinya pneumonia pada anak balita. ${ }^{25}$ Maksud dari gizi kurang adalah kekurangan energi protein yang terkandung didalam makanan sehari-hari yang mempengaruhi keadaan gizi anak. Menurut penelitian Rodriguez (2011) kekurangan gizi berkontribusi terhadap 56\% dari semua kematian anakanak di seluruh dunia. ${ }^{26}$ Selain itu penelitian di Solapur india juga menunjukkan hasil dari 160 anak usia dibawah lima tahun total hanya 44 (27,50\%) memiliki status gizi yang normal sisanya memiliki status gizi kurang, hasil dari analisis data nya menemukan hasil signifikan antara status gizi terhadap terjadinya ISPA dengan ( $\mathrm{p}<0,001$ ) dengan rasio odds 5,17 menunjukkan risiko 5,17 kali lebih buruk untuk terjadinya ISPA pada balita yang mempunyai status gizi kurang dibandingkan dengan yang mempunyai status gizi baik. ${ }^{27}$ Kemudian penelitian dari Sukmawati \& Sri Dara Ayu (2010) di wilayah kerja Puskesmas Tunikamaseang Kabupaten Maros Sulawesi juga menunjukkan kejadian ISPA 
berulang yang lebih banyak pada balita dengan status gizi kurang dengan $p=0,03$, hal ini disebabkan karena status gizi yang kurang menyebabkan ketahanan tubuh menurun dan virulensi patogen lebih kuat, sehingga akan menyebabkan keseimbangan terganggu dan akan terjadi infeksi. Salah satu determinan dalam mempertahankan keseimbangan tersebut adalah status gizi yang baik. Namun dari penelitian ini ditemukan juga responden yang berstatus gizi baik tetapi terkena ISPA. Hal ini disebabkan oleh faktor lain yang dapat menyebabkan terjadinya ISPA pada balita seperti umur, pemberian ASI, keteraturan pemberian vitamin A, polusi udara, sosial ekonomi, imunisasi kepadatan dalam rumah dan BBLR. Selain itu didapatkan juga responden yang berstatus gizi kurang tetapi tidak terkena ISPA. Hal tersebut bisa terjadi kemungkinan karena faktor lingkungan tempat tinggalnya yang tidak ada yang menderita ISPA meskipun status gizinya kurang, atau bisa dikarenakan mereka sudah mendapatkan imunisasi yang lengkap sehingga mereka mempunyai kekebalan tubuh terhadap serangan infeksi sehingga tidak mudah terkena ISPA. Dari hasil diatas dapat disimpulkan bahwa gizi mempunyai peran yang sangat besar dalam pemeliharaan kesehatan tubuh balita. Jika balita mengalami status gizi yang kurang maka akan lebih mempermudah kuman-kuman patogen menyerang tubuh sehingga terjadi ISPA. Maka dari itu untuk mengurangi angka kejadian ISPA maka status gizi balita harus selalu dijaga dan ditingkatkan.

Berdasarkan hasil penelitian tabel 4 menunjukkan bahwa mayoritas balita ISPA memiliki keluarga perokok aktif $(77,6 \%)$ sedangkan balita ISPA yang memiliki keluarga bukan perokok adalah $(22,4 \%)$. Rata-rata jumlah anggota keluarga balita kasus yang merokok yaitu 1 orang dengan paling sedikit tidak ditemukan perokok dan paling banyak ditemukan 2 orang perokok. Sebagian besar perokok mampu menghabiskan lebih dari 1 bungkus rokok perhari. Ketika sedang di rumah, seringkali perokok merokok di dalam satu ruangan yang sama dengan balita. Sehingga besar kemungkinan balita terpapar asap rokok tersebut. Hasil penelitian lain, Shibata (2014) menunjukkan bahwa pendapatan rumah tangga dan pendidikan ibu memiliki efek tidak langsung pada pneumonia anak dan penyakit pernapasan dengan data materi khusus berbeda secara signifikan antara kelompok kasus dan kelompok kontrol (p <0,01) ${ }^{28}$ Menurut Salvi (2009) di penelitiannya Asap tembakau lingkungan (ETS) adalah faktor risiko utama untuk kesehatan paru-paru yang buruk pada anak-anak. Paparan ETS telah terbukti berhubungan dengan peningkatan prevalensi infeksi saluran pernapasan atas, mengi, asma dan infeksi saluran pernapasan bawah. ${ }^{29}$ Hasil penelitian lainnya, Fernandez (2016) bahwa anak dengan yang sering menjadi perokok pasif memiliki fungsi paru yang lebih rendah dibandingkan anak yang tidak terpapar asap rokok dengan hasil spirometri anak yang terpapar adalah 6,8 dan $14,1 \mathrm{ml} .{ }^{30}$ Kemudian penelitian lainnya Wardani (2016) di Magelang berdasarkan hasil analisis dapat diketahui bahwa $\mathrm{p}$ $<0,05$ dan perhitungan koefisien korelasi sebesar 0,537 menunjukkan bahwa ada hubungan antara paparan asap rokok dengan kejadian Infeksi Saluran Pernapasan Akut (ISPA) pada balita di desa Pucung Rejo kabupaten Magelang. ${ }^{31}$ Asap rokok mengandung racun yang sangat berbahaya bagi sistem pernapasan manusia terutama perokok pasif. Rokok menjadi salah satu penyebab pneumonia 
karena asap rokok merusak sistem pertahanan paru dengan mengganggu fungsi silia dan kerja sel makrofag alveolus. Sehingga mikroorganisme masuk ke saluran pernapasan dan dengan mudah mencapai paru-paru kemudian merusak jaringan paru dengan cara mengeluarkan toksin, sehingga agen infeksius masuk ke dalam saluran pernapasan. Kemudian melakukan adhesi pada dinding bronkus dan bronkiolus, selanjutnya bermultiplikasi dan timbul pemicu terjadinya inflamasi. Pada saat terjadi inflamasi, kantung udara terisi dengan cairan eksudat yang banyak mengandung protein. Zat-zat racun dalam rokok dapat mematikan sistem kekebalan tubuh. Balita yang terpapar rokok pasif memiliki risiko lebih terkena penyakit infeksi karena sistem kekebalan tubuh balita tersebut jauh lebih lemah dibandingkan dengan balita yang jarang atau tidak sama sekali terpapar asap rokok.

\section{KESIMPULAN DAN SARAN}

Berdasarkan hasil penelitian yang telah dilakukan, didapatkan karakteristik pasien Hipertensi berdasarkan jenis kelamin menunjukkan bahwa jenis kelamin tidak masuk karakteristik pasien ISPA pada balita, berdasarkan usia didapatkan pada usia<3 tahun lebih banyak dibandingkan usia di atasnya dan berdasarkan karakteristik status gizi pada penderita ISPA pada balita didapatkan jumlah pasien dengan status gizi kurang jauh lebih banyak dibandingkan status gizi yang lain.Serta pasien yang ada perokok dalam keluarga didapatkan jumlah pasien lebih banyak dibandingkan yang tidak ada perokok dalam keluarga. Berdasarkan hasil yang didapatkan dapat dipahami bahwa dengan mengetahui beberapa faktor resiko yang berperan terhadap peningkatan terjadinya ISPA pada balita, maka kita juga dapat secara langsung mengendalikan terjadinya kasus ISPA tersebut. Dengan mengacu kepada hasil yang didapatkan, maka dapat dikatakan bahwa tidak hanya dengan menggunakan obat dapat mengendalikan kasus-kasus ISPA pada balita, tetapi dengan mengontrol beberapa faktor resiko juga dapat menurunkan kejadian ISPA pada balita.

\section{UCAPAN TERIMA KASIH}

Puji syukur kepada Allah SWT, karena atas segala rahmat dan bimbingan-Nya penulis dapat menyelesaikan Karya Tulis Ilmiah ini. Penulis juga berterima kasih kepada peneliti-peneliti sebelumnya, serta keluarga, dosen pembimbing dan teman-teman yang senantiasa memberikan do'a dan dukungan sehingga penulisan hasil karya tulis ilmiah ini dapat terselesaikan.

\section{DAFTAR PUSTAKA}

1. Permatasari C. Faktor Resiko Kejadian ISPA. In Jakarta: Fakultas Kesehatan Masyarakat Universitas Indonesia; 2009.

2. Anonim. Pedoman Kerja Puskesmas Jilid III. Jakarta: Departemen Kesehatan Republik Indonesia; 2001.

3. Yovita W. Evaluasi Program Pemberantasan Penyakit Infeksi Saluran Pernapasan Akut di Puskesmas kelurahan tanjung duren selatan periode Februarin 2009 - Januari 2010. Jakarta: kepanitraan IKM Fakultas Kedokteran UKRIDA; 2010.

4. Marcdante KJ. Nelson Ilmu Kesehatan Anak. In: Pediatrics. 2014.

5. Suhandayani I. Faktor-faktor yang berhubungan dengan kejadian ISPA pada balita di 
Puskesmas Pati I kabupaten Pati tahun 2006 [Internet]. Semarang: IKMFKUNNES; 2006. Available from: http://digilib.unnes.ac.id/gsdl/collect/skripsi/archives/HASH1450/712b0778.dir/doc.pdf

6. Kementerian Kesehatan Republik Indonesia. Laporan Nasional Riskesdas 2007. Badan Penelit dan Pengemb Kesehat Dep Kesehatan, Republik Indones Desember 2008. 2008;1-384.

7. Dharmage SC, Rajapaksa LC, Fernando DN. Risk factors of acute lower respiratory tract infections in children under five years of age. Southeast Asian J Trop Med Public Health. 1996;

8. Kementerian Kesehatan RI. RISKESDAS 2013. Jakarta; 2013.

9. Li T, Zhang Y, Gong C, Wang J, Liu B, Shi L, et al. Prevalence of malnutrition and analysis of related factors in elderly patients with COVID-19 in Wuhan, China. Eur J Clin Nutr. 2020;

10. Dinas Kesehatan Provinsi DIY. Profil Kesehatan Propinsi D.I.Yogyakarta Tahun 2014. Yogyakarta; 2014.

11. Kementerian Kesehatan RI 2010. Profil Kesehatan Indonesia. Jakarta: Kementerian Kesehatan Republik Indonesia; 2010.

12. Ujunwa F, Ezeonu C. Risk factors for acute respiratory tract infections in under-five children in Enugu Southeast Nigeria. Ann Med Health Sci Res. 2014;

13. Notoatmodjo S. Promosi Kesehatan \& Perilaku. Vol. 1, Jakarta: Rineka Cipta. 2007.

14. Marimbi H. Tumbuh Kembang Status Gizi, dan Imunisasi Dasar Pada Balita. Yogyakarta: Nuha Medika; 2010.

15. Koch A, Sørensen P, Homøe P, Mølbak K, Pedersen FK, Mortensen T, et al. Population-based study of acute respiratory infections in children, Greenland. Emerg Infect Dis. 2002;

16. Pudjiadin, Solihin. Ilmu gizi klinis pada anak. Fak. Kedokteran UI; 2005.

17. Kikuchi T, Andarini S, Xin H, Gomi K, Tokue Y, Saijo Y, et al. Involvement of fractalkine/CX3CL1 expression by dendritic cells in the enhancement of host immunity against Legionella pneumophila. Infect Immun. 2005;

18. Lamsidi A. Hubungan kondisi kesehatan lingkungan pemondokan dengan kejadian ISPA di Pondok Pesantren Sabilal Muhtadin Desa Jaya Karet kecamatan Mentaya Hilir Selatan Provinsi Kalimantan Tengah. Semarang: Pascasarjana, UNDIP; 2016.

19. LeMone, Priscilla; Burke, Karen M; Bauldoff G. BUKU AJAR KEPERAWATAN MEDIKAL MEDAH. Edisi 8 Volume 2. 2016.

20. Sahadulla M. Infections of the Respiratory System. In: Concise Handbook of Infectious Diseases. 2018.

21. Prasetyawati A. Kedokteran Keluarga dan Wawasannya. Surakarta: Universitas Negeri Surakarta; 2010.

22. Rahajoe NN, Supriyatno B SD. Buku Ajar Respirologi Anak. Badan Penerbit Ikat Dr Anak Indones. 2015;

23. Depkes RI. Anak dengan Gizi Baik Menjadi Aset dan Investasi Bangsa Di Masa Depan [Internet]. Kementerian Kesehatan RI. Jakarta; 2010 [cited 2020 May 6]. 1 p. Available from: https://www.kemkes.go.id/article/view/1346/anak-dengan-gizi-baik-menjadi-aset-dan-investasi-bangsa-di-masa-depan.html

24. Williams BG, Gouws E, Boschi-Pinto C, Bryce J, Dye C. Estimates of world-wide distribution of child deaths from acute respiratory infections. Lancet Infectious Diseases. 2002.

25. Fonseca SC, Coutinho E da SF. Perinatal mortality research in Brazil: review of methodology and results. Cadernos de saúde pública / Ministério da Saúde, Fundação Oswaldo Cruz, Escola Nacional de Saúde Pública. 2004.

26. Rodríguez L, Cervantes E, Ortiz R. Malnutrition and gastrointestinal and respiratory infections in children: a public health problem. International journal of environmental research and public health. 2011.

27. Pore PD, Ghattargi CH, Rayate M V. Study of Risk Factors of Acute Respiratory Infection (ARI) in Underfives in Solapur. Natl J Community Med. 2010;

28. Shibata T, Wilson JL, Watson LM, Leduc A, Meng C, Ansariadi, et al. Childhood acute respiratory infections and household environment in an eastern indonesian urban setting. Int $\mathbf{J}$ Environ Res Public Health. 2014;

29. Cheraghi M, Salvi S. Environmental tobacco smoke (ETS) and respiratory health in children. European Journal of Pediatrics. 2009. 
30. Fernández-Plata R, Rojas-Martínez R, Martínez-Briseño D, García-Sancho C, Pérez-Padilla R. Effect of Passive Smoking on the Growth of Pulmonary Function and Respiratory Symptoms in Schoolchildren. Rev Invest Clin. 2016;

31. Wardani NK, Winarsih S, Sukini T. Hubungan Antara Paparan Asap Rokok Dengan Kejadian Infeksi Saluran Pernapasan Akut (Ispa) Pada Balita Di Desa Pucung Rejo Kabupaten Magelang. J Kebidanan. 2016; 